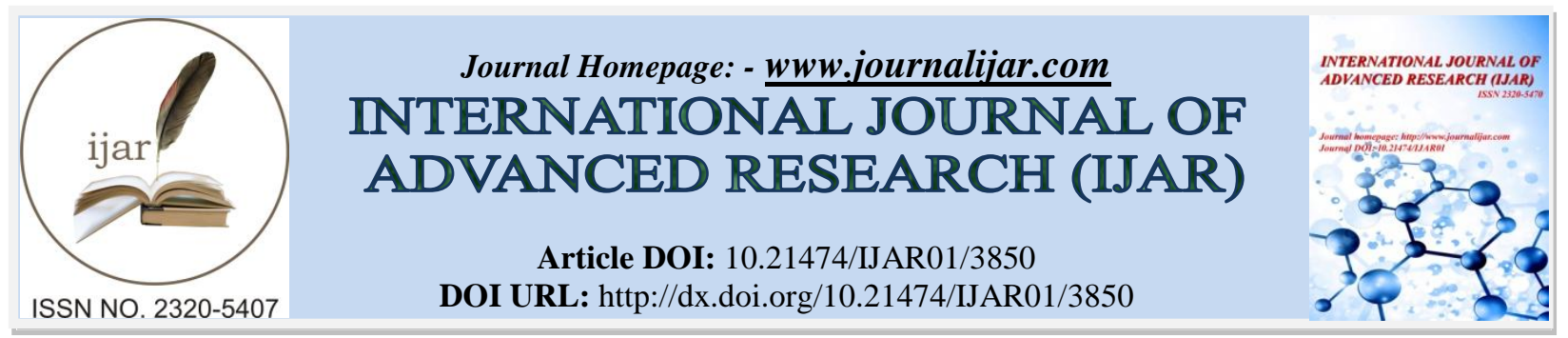

RESEARCH ARTICLE

\title{
STUDIES ON MICROSTRUCTURES AND PROCESSING OF SS409M SHEET.
}

\section{Manimaran, S.Vigneshwaran, S. Sakthivel, J. Mathan and S.Tamilvanan.}

1. Department of Mechanical Engineering, K.S.Rangasamy College of Technology Tiruchengode, Namakkal, Tamilnadu, India.,

2. Department of Mechanical Engineering, K.S.R.I.E.T Tiruchengode, Namakkal, Tamilnadu India

\section{Manuscript Info}

Manuscript History

Received: 07 February 2017

Final Accepted: 01 March 2017

Published: April 2017

Key words:-

SS409M, CR+AC, Microstructures,

Mechanical properties

\begin{abstract}
An SS409M steel sheet with a tensile strength over $1400 \mathrm{MPa}$ and very good, of highest quality force of meeting below toughness was got by either using controlled rolling plus air cooling or laboratorial thermo-mechanical controlled processing . The effects of $\mathrm{CR}+\mathrm{AC}$ and the TMCP processes were then inspected on the microstructures and mechanical quality of this stainless steel sheet. The results showed that by using $\mathrm{CR}+\mathrm{AC}$ technology an equally distributed bainitic ferrite microstructure could be produced in this steel sheet under the right reheating and rolling condition. By using TMCP technology, a thin narrow bit of bainite and martensitic microstructure with superior mechanical properties could also be generated. A micro structural analysis was made to interprete the strengthening-toughening mechanisms in connection with the processes
\end{abstract}

Copy Right, IJAR, 2017,. All rights reserved.

\section{Introduction:-}

Type SS $409 \mathrm{M}$ is a modified version of SS 409 with lower carbon content (0.03\%). It replaces carbon steels and low alloy steels where higher strength, abrasion resistance, weld-ability and slide-ability are required. It posses good scaling \&oxidation resistance at elevated temperature including sulphur bearing atmospheres It finds application in bulk solids handling areas/bunkers, transport (wagons), petrochemical, sugar, agriculture, fishing, mining \& quarrying, sewage plants and general engineering industries The microstructure of stainless steel is a metastable aggregate of ferrite and cementite, which was produced from the austenite transformation at temperature below the pearlite range and above the martensite starting temperature (Aglan et al., 2004). By multi-elemental alloying and deliberately microstructural control via appropriate processing, the bainitic steel can be made with ultra-high strength and excellent fracture toughness (Caballero and Bhadeshia, 2004; Sourmail and Smanio, 2013). In order to develop new generation of high strength steel with sufficient wear resistance, the steels with bainitic microstructure that could achieve ultra-high strength and also higher plastic characteristics became the background for developing such new structural steels, e.g. in the production of steel rail (Hlavatý et al., 2009). It is known that high carbon bainitic and martensitic steels were not used as rail steel in the past. Instead, high carbon pearlitic steels have long been produced as the steel rail material (Khourshid et al., 2001), because highcarbon bainitic steel is less wear resistant than fine pearlitic steel. Similarly, the plate martensite is also brittle and susceptible to micro-cracks (Singh et al., 2001). Moreover, heat treatment approach to obtaining martensite is an economically and environmentally costly step to the manufacturing route. Thus, bainitic steels are gaining ground as an alternative to quenched and tempered steels (Sourmail and Smanio, 2013). In comparison with pearlitic rail steels, bainitic rail steels possess

Corresponding Author:- V. Manimaran.

Address:- Department of Mechanical Engineering, K.S.Rangasamy College of Technology Tiruchengode, 
superior flaking resistance, good wear resistance and excellent weldability (Yokohama et al., 2001). Although ss409M stainless steels have merits of high toughness, high wear resistance, impact resistance and rolling contact fatigue resistance, the processing and mechanical properties pertinent to the industrial production route remain to be understood, especially those related to the cooling conditions after hot deformation. In this study, SS409M stainless steel was utilized as experimental material to investigate the effects of processing condition on the microstructures and mechanical properties of this ultra-high strength plate steel. Emphasis of this study was put on the examination and characterization of microstructural change and mechanical properties when controlled rolling plus air cooling $(\mathrm{CR}+\mathrm{AC})$ and thermo-mechanical controlled processing (TMCP) had been used for preparing this low carbon stainless steel sheet.

\section{Experimental procedure:-}

The chemical composition of the steel sheet in this study was optimized by Thermo- calculation and is similar to that of J6 bainitic rail steel (Aglan et al., 2004; Hlavatý et al., 2009). When compared with pearlitic rail steel, we may note that this steel has low carbon content and was alloyed with multiple elements. In a laboratory induction vacuum furnace, a $150 \mathrm{~kg}$ ingot was smelted and cast. The ingot was then forged into slab with a transversal size of $90 \times 90$ mm. Table 1 lists its chemical composition. The chemical composition of the steel sheet in this study was optimized by Thermo-Calc calculation and is similar to that of J6 bainitic rail steel (Aglan et al., 2004; Hlavatý et al., 2009). When compared with pearlitic rail steel, we may note that this steel has low carbon content and was alloyed with multiple elements. In a laboratory induction vacuum furnace, a $150 \mathrm{~kg}$ ingot was smelted and cast. The ingot was then forged into slab with a transversal size of $90 \times 90 \mathrm{~mm}$. Table 1 lists its chemical composition.

Table 1:- Chemical composition of experimental steel (in wt pct).

\begin{tabular}{|c|c|c|}
\hline Elements & $\begin{array}{c}409 \mathrm{M} \\
\text { (Annealed) }(\%)\end{array}$ & $\begin{array}{c}409 \mathrm{M} \\
\text { (Normalized) }(\%)\end{array}$ \\
\hline $\mathrm{C}(\max )$ & 0.018 & 0.025 \\
\hline $\mathrm{Mn}(\max )$ & 0.82 & 0.85 \\
\hline $\mathrm{Si}(\max )$ & 0.42 & 0.59 \\
\hline $\mathrm{S}(\max )$ & 0.014 & 0.015 \\
\hline $\mathrm{P}(\max )$ & 0.030 & 0.024 \\
\hline $\mathrm{Cr}$ & 11.12 & 11.35 \\
\hline $\mathrm{Ni}$ & 0.30 & 0.40 \\
\hline $\mathrm{N}(\max )$ & 0.017 & 0.020 \\
\hline
\end{tabular}

Cold charging was used to simulate industrial reheating process. The ingot was heated to $1200{ }^{0} \mathrm{C}$ in an electric furnace and kept for $120 \mathrm{~min}$. Controlled rolling at two stages, i.e. recrystallized (Stage 1) and unrecrystallized regions (Stage 2), was conducted for the ingot and the final thickness of the steel sheet is $12 \mathrm{~mm}$. At recrystallized region, the initial rolling temperature is $1150 \sim 1050{ }^{\circ} \mathrm{C}$, while at unrecrystallized region the starting temperature is 950 900 ${ }^{\circ} \mathrm{C}$. The finish rolling temperatures at these two stages are $1000{ }^{\circ} \mathrm{C}$ and $850 \mathrm{oC}$, respectively, and the accumulated rolling reduction ratio is over $60 \%$ at each stage. In order to have an optimal processing technology and consider the cooling mode, effects of $\mathrm{CR}+\mathrm{AC}$ (process I) and TMCP (process II) were investigated on the microstructures and mechanical properties of this steel. Fig. 1 summarizes the rolling schedules and subsequent cooling modes. The detailed information on the controlled rolling and cooling is presented in Table 2.

Table 2:- Measured processing parameters during two-stage hot rolling and subsequent cooling.

\begin{tabular}{|l|l|l|l|l|l|}
\hline Route & $\begin{array}{l}\text { Start rolling } \\
\text { temperature } \\
\text { stage 1 }\end{array}$ & $\begin{array}{l}\text { Finish rolling } \\
\text { temperature at } \\
\text { stage 1 }\end{array}$ & $\begin{array}{l}\text { Start rolling } \\
\text { temperature at } \\
\text { stage 2 }\end{array}$ & $\begin{array}{l}\text { Finish rolling } \\
\text { temperature } \\
\text { stage 2 }\end{array}$ & $\begin{array}{l}\text { Cooling rate } \\
\text { After CRA }\end{array}$ \\
\hline $\mathrm{CR}+\mathrm{AC}(\mathrm{I})$ & $1090^{\circ} \mathrm{C}$ & $1072^{0} \mathrm{C}$ & $912^{0} \mathrm{C}$ & $885^{0} \mathrm{C}$ & Air cooling \\
\hline TMCP (II) & $1060^{\circ} \mathrm{C}$ & $1040^{\circ} \mathrm{C}$ & $908^{0} \mathrm{C}$ & $891^{0} \mathrm{C}$ & $15^{0} \mathrm{C} \cdot \mathrm{s}^{-1}$ \\
\hline
\end{tabular}

The specimen for metallographic observation was sectioned along the rolling direction. After mechanical grinding and polishing, they were etched in 4 vol.\% HNO3 alcohol solution and then observed at a DM 2500M optical microscope. The more refined microstructures were observed at Quanta 600 scanning electron microscope (SEM) and a TecnaiG2 F20 transmission electron microscope (TEM). 


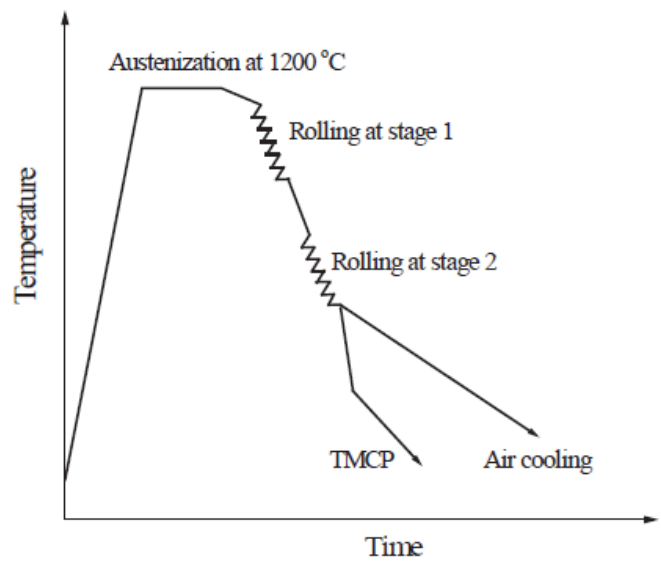

Fig. 1:- Schematic diagram showing processing routes of SS409 M steel sheet.

Vickers hardness was measured in FM-700 testing machine with load of $100 \mathrm{~g}$ and loading time of $15 \mathrm{~s}$. The tensile and V-notch Charp impact specimens were machined also along the rolling direction. The tensile test was conducted on a WAW-1000 electro-hydraulic servo universal testing machine with a strain rate of $10^{-3} \mathrm{~s}^{-1}$, while the impact test was carried out on Instron $9250 \mathrm{HV}$ floor type of instrumented impact test machine at room temperature and $-30{ }^{\circ} \mathrm{C}$.

\section{Results and Discussion:-}

Figs. 2(a) and (b) show the optical microstructures of this steel processed by CR+AC (I) and TMCP (II), respectively, while the SEM microstructures after these two routes are presented in Figs. 3(a) and (b). Considering the hot rolling schedule used in this study, we may find that the microstructure in Figs. 2(a) and 3(a) is bainite and those after TMCP can be ascribed to a mixture of lath martensite and bainite as shown in Figs. 2(b) and 3(b).

Table 3:- Tensile mechanical properties and hardness of experimental steel sheet processed by two different routes

\begin{tabular}{|l|l|l|l|l|l|l|}
\hline Route & $\begin{array}{l}\text { Tensile } \\
\text { strength } \\
(\mathrm{MPa})\end{array}$ & $\begin{array}{l}\text { Yield } \\
\text { strength } \\
(\mathrm{MPa})\end{array}$ & $\begin{array}{l}\text { Yield } \\
\text { ratio }\end{array}$ & $\begin{array}{l}\text { Elongation } \\
(\%)\end{array}$ & $\begin{array}{l}\text { Area } \\
\text { Reduction } \\
(\%)\end{array}$ & $\begin{array}{l}\text { Hardness } \\
(\mathrm{HV})\end{array}$ \\
\hline CR+AC(I) & 1550 & 1032 & 0.65 & 13.75 & 35.6 & 486 \\
\hline TMCP (II) & 1545 & 1020 & 0.66 & 11.9 & 31.4 & 532 \\
\hline
\end{tabular}
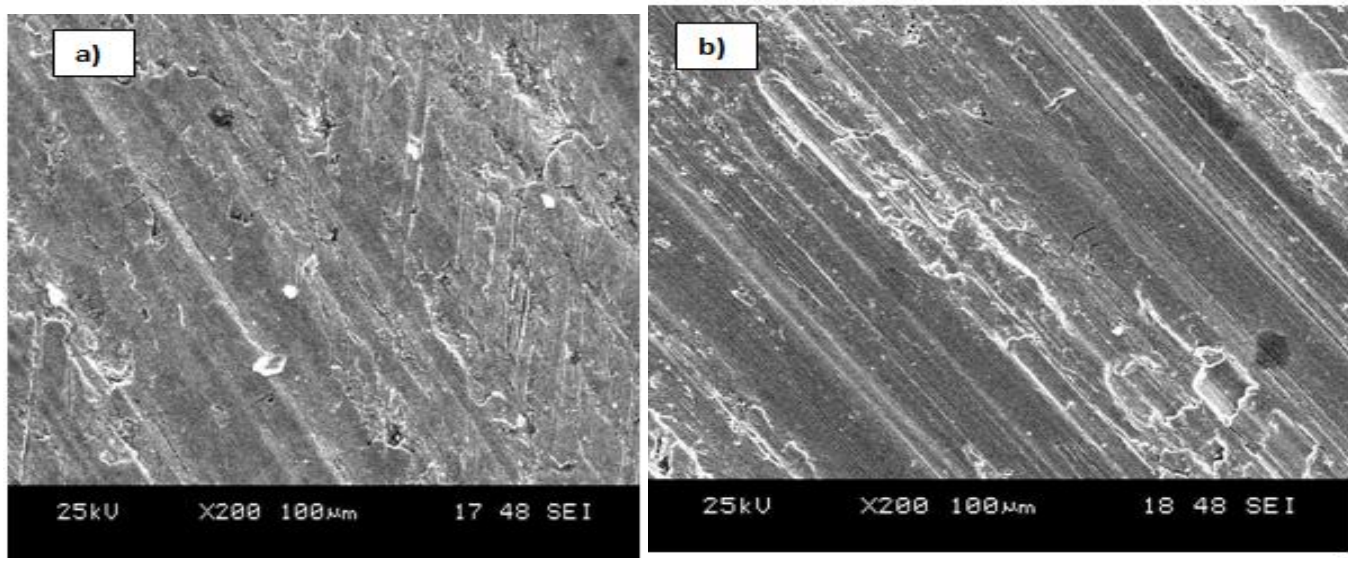

Fig. 2:- SEM micrographs showing tensile fractured surfaces of experimental steel processed by CR+AC (a) and TMCP (b). 


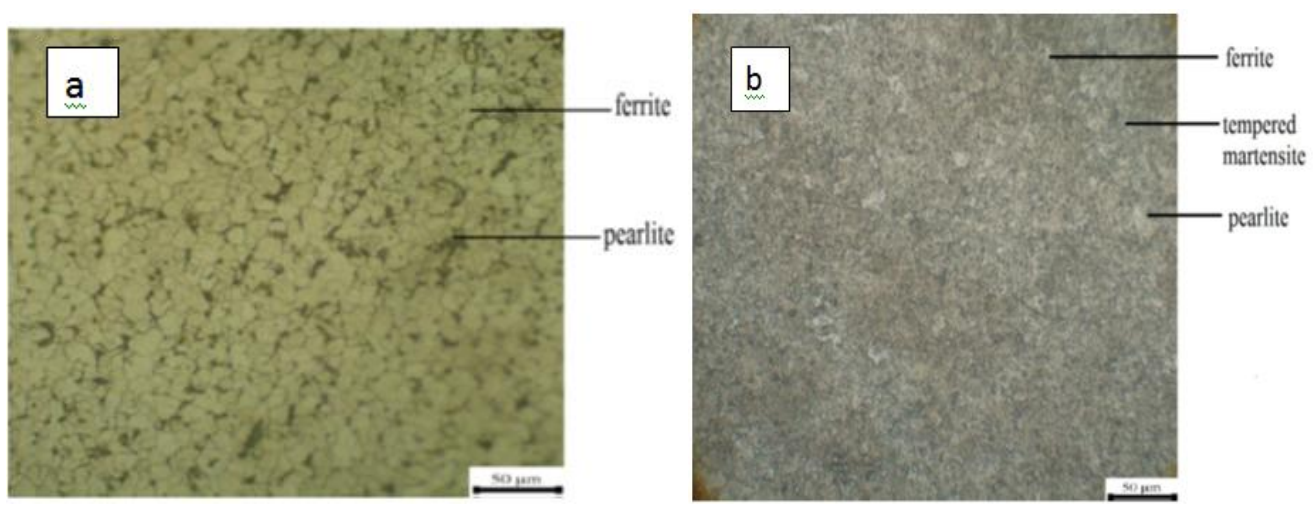

Fig. 3:- SEM micrographs showing microstructures of experimental steel processed by different routes: (a) CR+AC; (b) TMCP

The SEM micrographs of the tensile fractured surfaces processed by these two routes are presented in Fig. 4. From the macrographs showing the fractured surfaces in Figs. 4(a) and (b), it is evident that the specimens were ductile fractured depending on the processing condition. The most striking feature accompanied with fracture is plastic deformation by slip which produce large amount of slip deformation in crystal prior to ductile fracture. Moreover, there coexist more deeply equi-axed and elongated dimples in Fig. 4(a), which suggests that process I (CR+AC) is beneficial to the plasticity.

Table 4:- Impact behaviour of experimental steel sheet processed by two different routes.

\begin{tabular}{|l|l|l|l|l|}
\hline Route & $\begin{array}{l}\text { Impact energy } \\
(\mathrm{J})\end{array}$ & $\begin{array}{l}\text { Impact toughness } \\
\left(\mathrm{J} \cdot \mathrm{cm}^{-2}\right)\end{array}$ & $\begin{array}{l}\text { Impact energy } \\
(\mathrm{J})\end{array}$ & $\begin{array}{l}\text { Impact } \\
\text { toughness } \\
\left(\mathrm{J} \cdot \mathrm{cm}^{-2}\right)\end{array}$ \\
\hline CR+AC (I) & 48 & 55.5 & 38 & 47.9 \\
\hline TMCP (II) & 51 & 51.5 & 42 & 52.1 \\
\hline
\end{tabular}
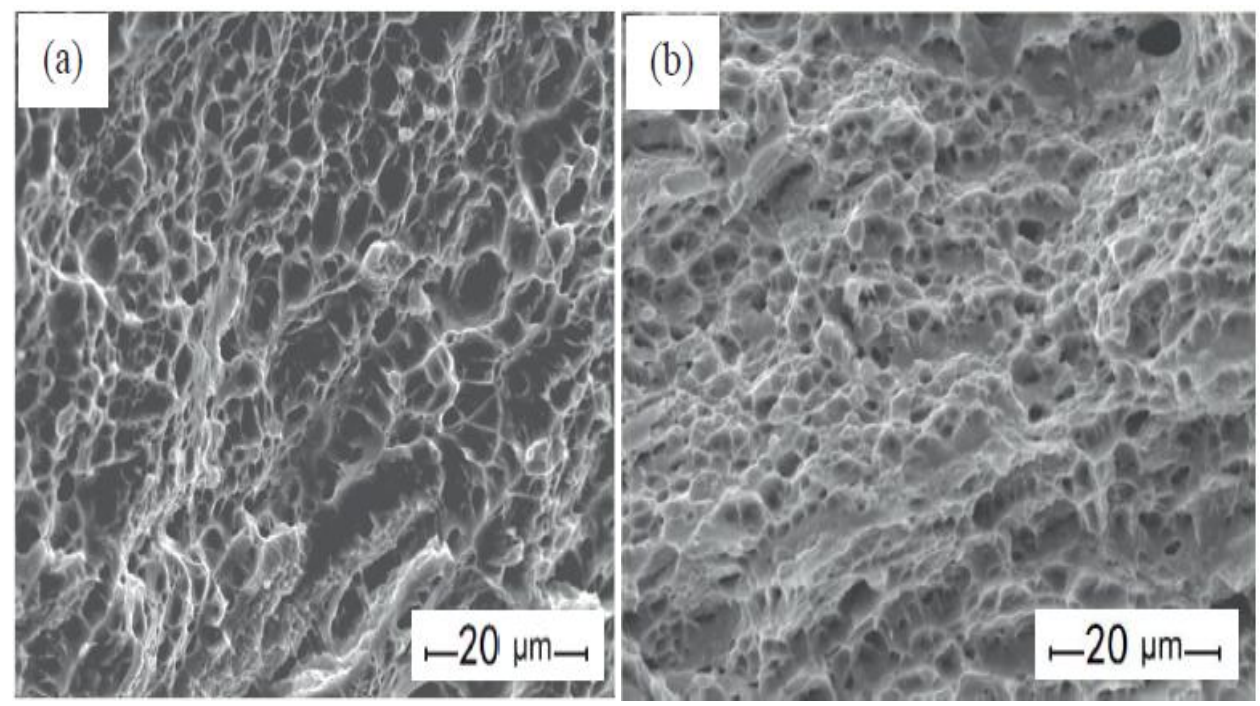

Fig. 4:- SEM micrographs showing tensile fractured surfaces of $C R+A C$ (a) and TMCP (b). 

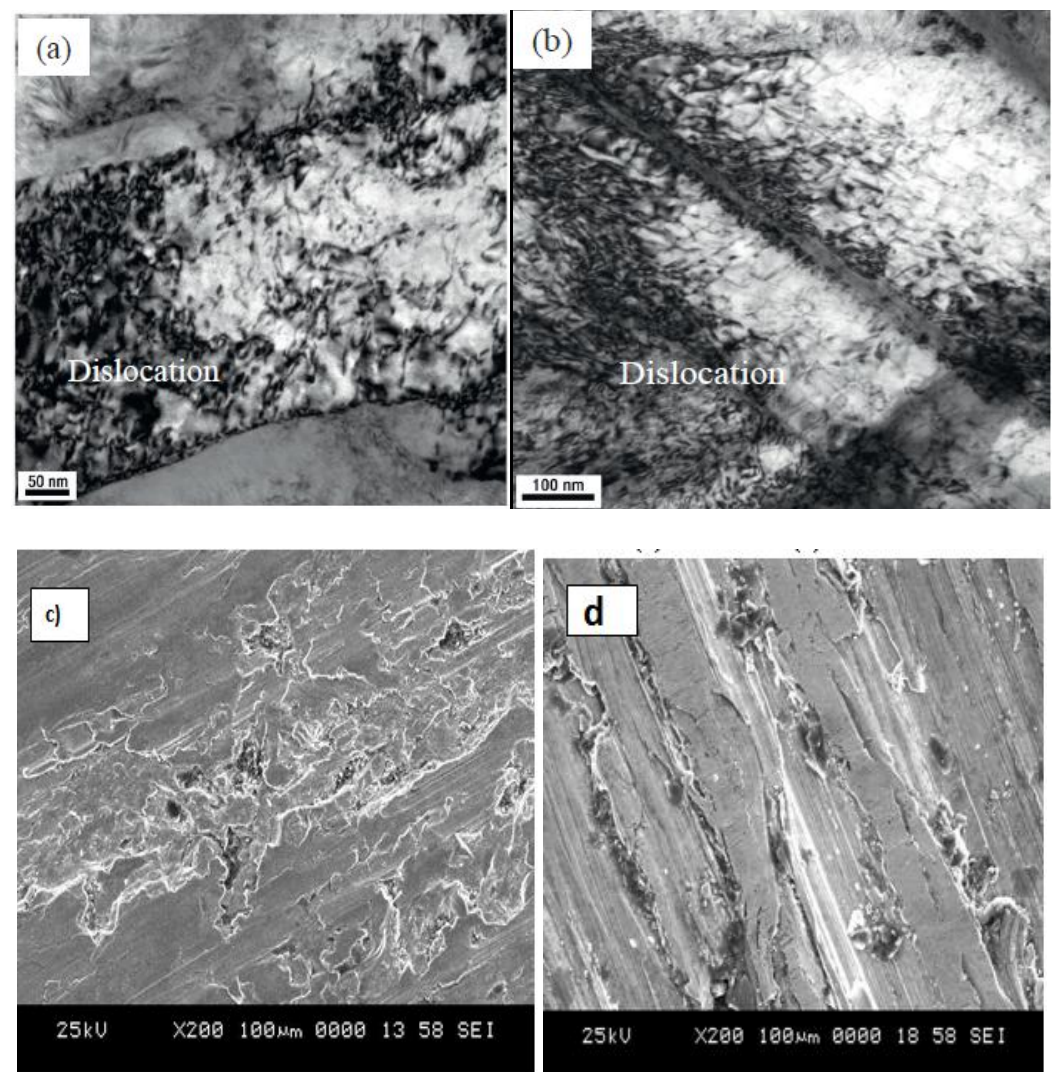

Fig. 3:-TEM micrographs of CR+AC (I) and TMCP (II) routes.

The impact energy and impact toughness of this SS409M sheet at room temperature and $-30{ }^{0} \mathrm{C}$ are presented in Table 4. At either room temperature or $-30{ }^{\circ} \mathrm{C}$, there was no much difference in the impact energy and toughness for process II. At $-30{ }^{\circ} \mathrm{C}$, the impact energy and toughness were decreased a little than that at room temperature for process I. This indicates that the experimental steel after TMCP has good low-temperature impact toughness. For both TMCP and $\mathrm{CR}+\mathrm{AC}$ processes, the impact energies at $-30{ }^{\circ} \mathrm{C}$ of this experimental bainitic steel are much higher than that reported by Wang et al. (2010). Fig. 5 shows the TEM microstructures of the experimental steel processed by CR+AC (I) and TMCP (II). From Fig. 5(c), one can see that the microstructures consist of fine lath bainite (LB) and retained austenite after process $\mathrm{I}$, where the width of the laths is $0.2 \sim 0.3 \mu \mathrm{m}$ and retained austenite film is located between the laths. It is obvious from Fig. 5(d) that the microstructures after process II is mainly composed of martensite (M), and minor fine lath bainite and residual austenite. The width of the laths is also $0.2 \sim 0.3 \mu \mathrm{m}$ and austenite film is also located between adjacent laths. Figs. 5(a) and (b) show the high-density dislocation wall at the bundle of bainite and martensite. It is readily to know that phase transformation of austenite to martensite and/or bainite plays most dominant strengthening role in this steel. Besides, fine dispersed precipitates were distributed within the laths and exert pinning effect on the dislocation movement, so precipitation strengthening is also important. The fine precipitates have several nanometres or less than $10 \mathrm{~nm}$, the tangled dislocations were pinned by these fine precipitate which lead to higher strength and excellent toughness of the steel.

\section{Conclusions:-}

The effects of $\mathrm{CR}+\mathrm{AC}$ and the TMCP processes were were made observation of on the microstructures and mechanical Properties of this stainless steel sheet. The following conclusions reasoning can be outlined.

1. After processed by either $\mathrm{CR}+\mathrm{AC}$ or TMCP, the microstructures of this steel sheet form of thin, narrow bit of wood bainite or thin, narrow bit of wood martensite plus thin, narrow bit of wood bainite. Under both the processing conditions, the give in andtensile forces of this steel be greater than $1000 \mathrm{MPa}$ and $1500 \mathrm{MPa}$,separately, while the Total elongation is over $10 \%$. The force of meeting blow behavior of is excellent at room temperature or even at greatly low temperature.

2. Fine precipitates $(<11 \mathrm{~nm})$ and high-density twisted dislocation are made distributed within the matrix after processed by either $\mathrm{CR}+\mathrm{AC}$ or TMCP. The strengthening and toughening mechanisms of this steel sheet can be 
attributed to fine precipitates and microstructural transformation of austenite to bainite or martensite. Both $\mathrm{CR}+\mathrm{AC}$ and TMCP processes can meet the requirement for producing extra-high Strength steel in a real production.

\section{References:-}

1. Aglan,H. A., Liu, Z.Y., Hassan, M.F., Fateh, M., 2004.Mechanical and Fracture Behavior of Bainitic Rail Steel. Journal of Materials Processing Technology 151(1-3), 268-274

2. Caballero, F.G., Bhadeshia, H.K.D.H., 2004.Very Strong Bainite.Current Opinion in Solid State and Materials Science 8(3-4), 251-257

3. Sourmail, T., Smanio, V., 2013. Optimisation of the Mechanical Properties of Air Cooled Bainitic Steel Components through Tailoring of the Transformation Kinetics. Materials Science and Engineering A 582, 257261.

4. Hlavatý, I., Sigmund, M., Krej, L., Mohyla, P., 2009. The Bainitic Steel for Rail Applications. Materials Engineering 16(4), 44-50.

5. Khourshid, A.M., Gan, Y.X., Aglan, H.A., 2001. Microstructure Origin of Strength and Toughness of a Premium Rail Steel. Journal of Materials Engineering and Performance 10(3), 331-336.

6. Singh, U.P., Roy, B., Jha, S., Bhattacharyya, S.K., 2001. Microstructure and Mechanical Properties of As Rolled High Strength Bainitic Rail Steels. Materials Science and Technology 17(1), 33-38.

7. Wang, L.J., Cai, Q.W., Yu, W., Wu, H.B., Lei, A.D., 2010. Microstructure and Mechanical Properties of 1500 MPa Grade Ultra-high Strength Low Alloy Steel. Acta Metallurgica Sinica 46(6), 687-694.

8. Yokoyama, H., Mitao, S., Yamamoto, S., Kataoka, Y., Sugiyama, T., 2001. High Strength Bainitic Steel Rails for Heavy Haul Railways with Superior Damage Resistance. NKK Technical Review, No.84, 44-51.

9. P.S.Sampath, V.Manimaran, A.Gopinath, M.M.Gobisankar 2016. "wear and corrosion studies on ferritic stainless steel (SS 409M)" eISSN: 2319-1163 pISSN: 2321-7308 